\title{
Spatio Temporal Monitoring of Urban Sprawl using GIS and Remote Sensing Technique
}

\author{
Pradeep Aswal \\ Project Assistant Department of \\ Civil Engineering \\ Geomatics Department, \\ IIT-Roorkee, Roorkee
}

\author{
Ritu Saini \\ Project Associate Department of \\ Civil Engineering \\ Geomatics Department, \\ IIT-Roorkee, Roorkee
}

\author{
Mohd Tanzeem Ansari \\ B.Tech 4th Year Department of \\ Civil Engineering Quantum \\ University Roorkee, \\ Uttarakhand
}

\begin{abstract}
Indian urbanization statistics experienced an unprecedented rate of growth over the last 30 years. Besides the three current mega cities (Delhi, Mumbai and Kolkata), nine more urban agglomerations in India (Ahmadabad, Bengaluru, Chennai, Hyderabad, Jaipur, Poona, Kanpur, Lucknow, Surat) currently have more than 2.5 million inhabitants. There is an immediate need to study, understand and quantify the urban sprawl in a more comprehensive way for these emerging urban centers. The current paper conducts a spatiotemporal analysis using two different images of Landsat satellite to detect urban footprints and their change in 20 years in Kanpur city of Uttar Pradesh state of India. Multi ring buffer analysis helps to more clearly distinguish these changes within the segment of $2 \mathrm{~km}$ from city center. The study shows that there is a remarkable growth in urban sprawl at the outskirts of the city.
\end{abstract}

\section{Keywords}

Remote Sensing, GIS, Multi Ring Buffer, Change Detection, Urban sprawl

\section{INTRODUCTION}

Urban growth is a dynamic process and understanding the relationship between growth and its driving factors, is a primary objective in the urban research agenda. Increase in urban growth is usually associated with the population concentration in an area which drives the change in land use land cover pattern. Analysis of urban growth pattern is a continuous process that involves scientists, resource managers and planners (Pathan et al., 1989; Pathan et al., 1991; Barnes et al., 2001; Angel et al., 2007; Kumar et al., 2007). The conventional surveying and mapping techniques are expensive and time consuming for the estimation of urban sprawl and such information is not available for most of the urban centers, especially in developing countries. As a result, increased research interest is being directed to the mapping and monitoring of urban sprawl/growth using GIS and remote sensing techniques (Epstein et al., 2002, Tiwari \& Dixit., 2015).

In the recent years, GIS has been adopted rapidly in urban sprawl assessment and modeling studies (Tiwari \& Jain, 2014). GIS is now widely used to create digital geographic database and it has also helpful for creation of input data for various models and to display the results of model outputs. GIS, combing all data in a logical structure that link to a computing environment, provides a powerful tool for land use land cover change assessment and urban sprawl modeling studies. A land use land cover GIS database offers facilities for urban sprawl modeling. These functions allow primarily overlay or index operations, but newly available GIS functions support the requirement of process based approaches (Tiwari et. al., 2018). Remote sensing is a tool that uses efficient sensors to extract valuable information in terms of reflectance. To record data a sensor measures the amount of electromagnetic energy reflected or emitted by an object. Further, mathematical, heuristic or knowledge based algorithms have been used to extract the information from the data collected by sensors. Remote sensing provides spatially consistent data sets that cover large areas with both high spatial details and high temporal frequency. The importance of remote sensing was emphasized as a "unique view" of the spatial and temporal dynamics of the processes in urban growth and land use change (Herold et al., 2003). Satellite remote sensing techniques in integration with GIS spatial analysis algorithms have therefore, been widely used in detecting and monitoring land cover change at various scales with useful results (Stefanov et al., 2001, Wilson et al., 2003).

In this study urban growth patterns of Kanpur city are mapped using two satellite imagery of year 2008 and 2016. A basic remote sensing built up index based technique is used to compute urban class in both the satellite imagery. In order to estimate the changing pattern of urban sprawl from the city center, the study maps implement multi ring buffer analysis over both the satellite images. Result are computed and presented in the form of graph to draw a clear perspective on Kanpur rapidly urbanizing residential and commercial zones.

\subsection{Study Area}

Kanpur is the 11th most populous urban city in India and the second largest city in the state of Uttar Pradesh after Lucknow. It is situated in the lower section of the Ganga and Yamuna between the parallels of $25^{\circ} 26^{\prime}$ and $26^{\circ} 58^{\prime}$ North latitude and $79^{\circ} 31^{\prime}$ and $80^{\circ} 34^{\prime}$ East longitude, falling in Survey of India Toposheet No. 63B7 (Figure1). The geographical area of the city is about 403.70 sq.km. Kanpur is divided into 2 districts the Kanpur Nagar (Kanpur Urban) and the Kanpur Dehat (Kanpur Rural). Kanpur Nagar includes the metropolis and the satellite villages around the city while Kanpur Dehat includes the towns other than Kanpur city. 

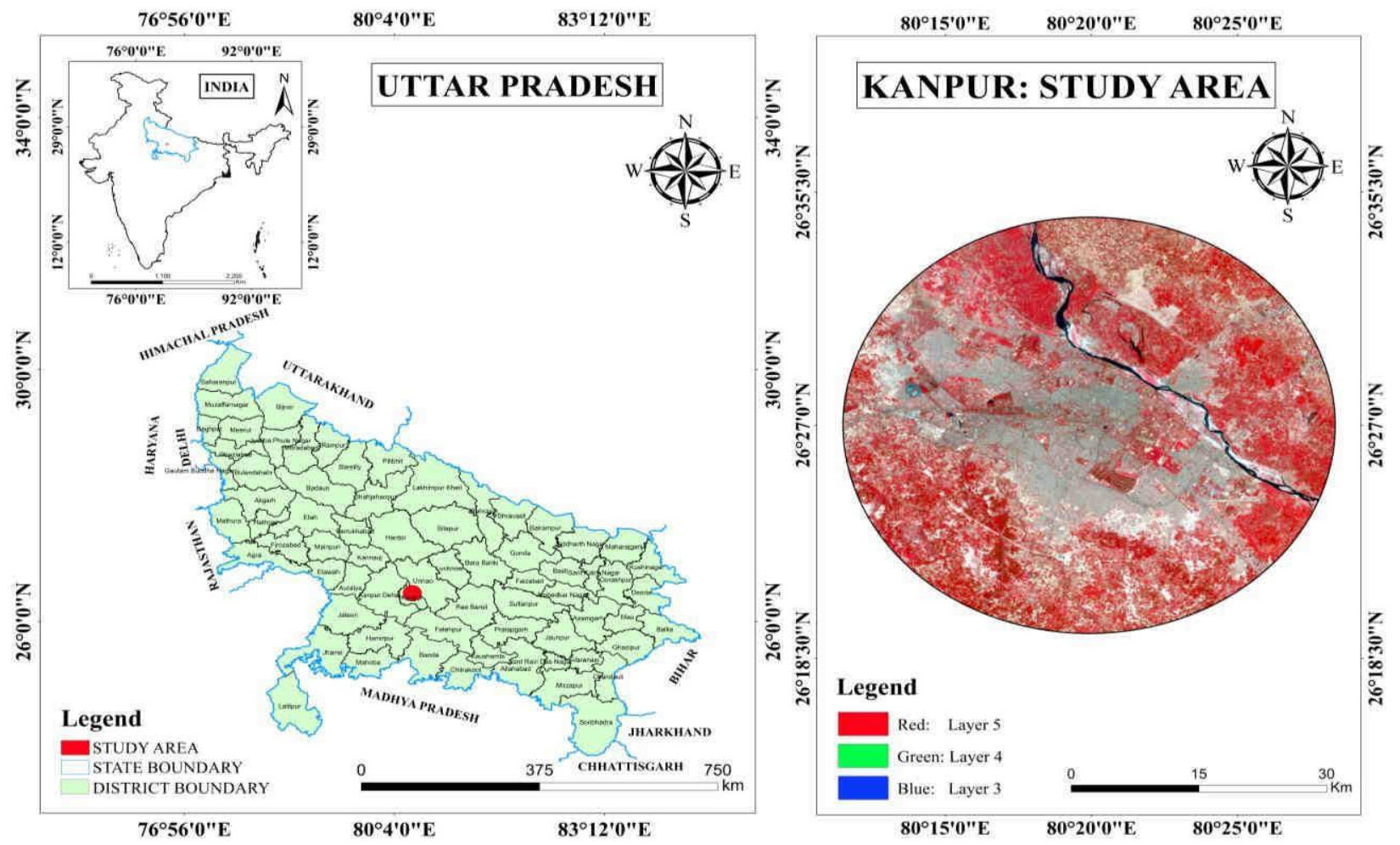

Figure1. Location Map of the Study Area

\subsection{DATA USED}

Openly available Landsat Satellite images of 2008 and 2016 are the primary dataset of current study. Both the images are downloaded from USGS earth explorer web portal (https://www.usgs.gov/earthexplorer). The detailed specifications of the satellite data is presented in the table.
Table1. Data used table for selected satellite data products

\begin{tabular}{|l|l|l|l|l|l|}
\hline Satellite & Sensor & Path & Row & $\begin{array}{l}\text { Acquisition } \\
\text { Date }\end{array}$ & $\begin{array}{l}\text { Resolution } \\
(\mathbf{m})\end{array}$ \\
\hline Landsat 5 & $\begin{array}{l}\text { MSS/ } \\
\text { T M }\end{array}$ & 144 & 42 & $11-02-2008$ & $30 / 100$ \\
\hline Landsat 8 & $\begin{array}{l}\text { OLI/TI } \\
\text { RS }\end{array}$ & 144 & 42 & $20-03-2016$ & $30 / 100$ \\
\hline
\end{tabular}

\section{SATELLITE MAP KANPUR
2008}

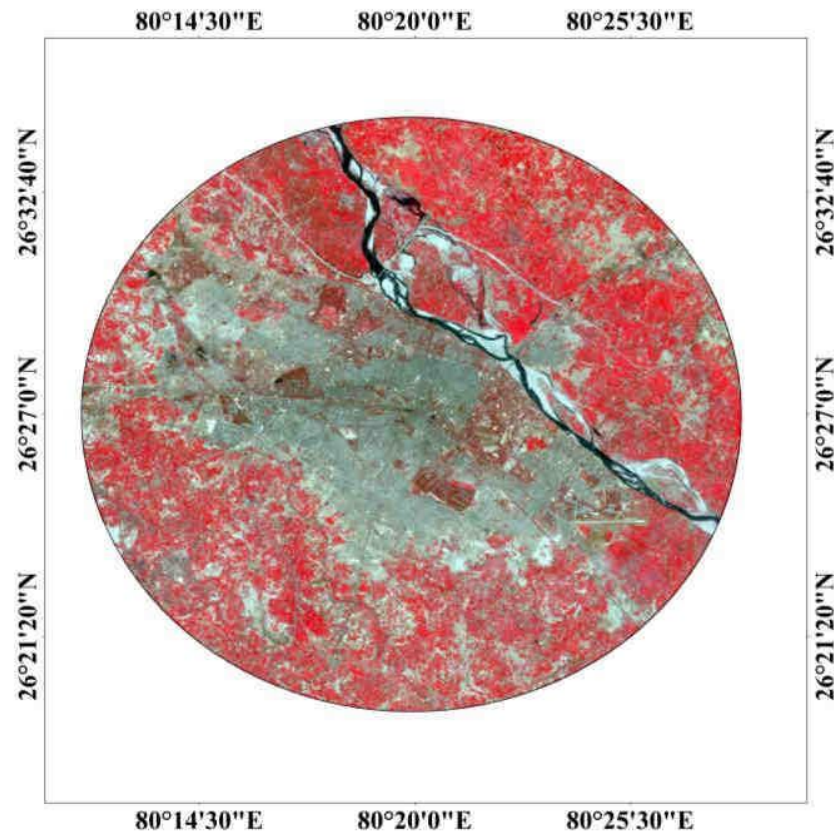

Figure2. (a) Satellite map of Study Area 


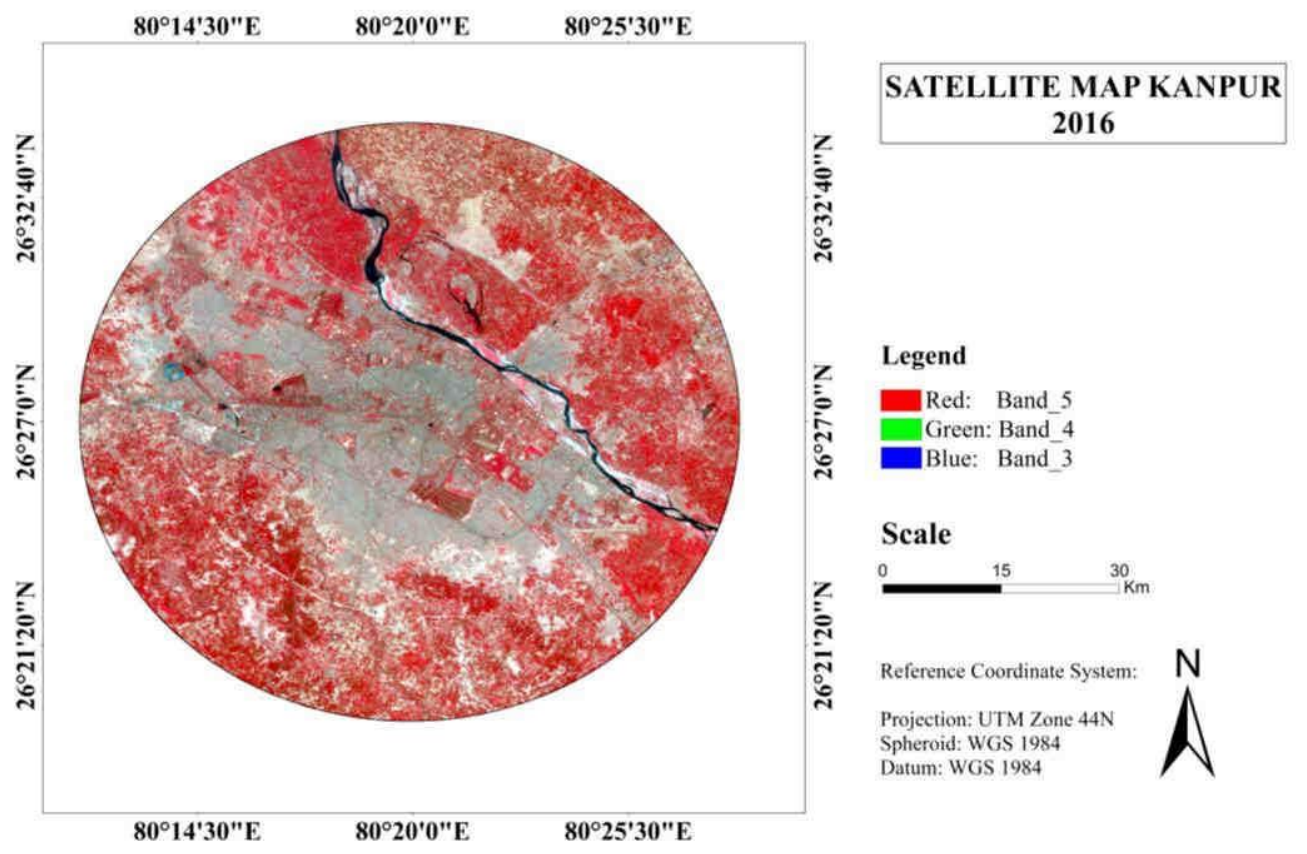

Figure2. (b) Satellite map of Study Area

\section{METHODOLOGY}

The methodology adopted for current study is depicted in figure 3. Study uses a data set comprising of satellite imagery of Landsat-5 and Landsat- 8 satellite for the year 2008 and 2016, both the satellite images were downloaded, stacked and cropped with the boundary of study area using ERDAS Imagine software. Using the model maker tool in ERDAS Imagine software, NDBI is computed. Manual thresholding with ground validation helps to select specific NDBI threshold value for both the images. Thresholding helps to extract urban extent of the city. In case of 2008 image threshold is 0.20 and in case of 2016 it is 0.07 . In order to compute the change detection between both the selected years, a multi ring buffer analysis approach is used. Study is divided into seven different buffers of $2 \mathrm{~km}$ radius. For each buffer urban area is extracted from the urban extent map of 2008 and compared with the corresponding urban buffer value of 2016. This detailed investigation helps to measure the urban landscape dynamics for rapidly urbanizing Kanpur city. Selected Multi ring buffer analysis not only measures urban concentration but also helps to understand its correction with city morphology.

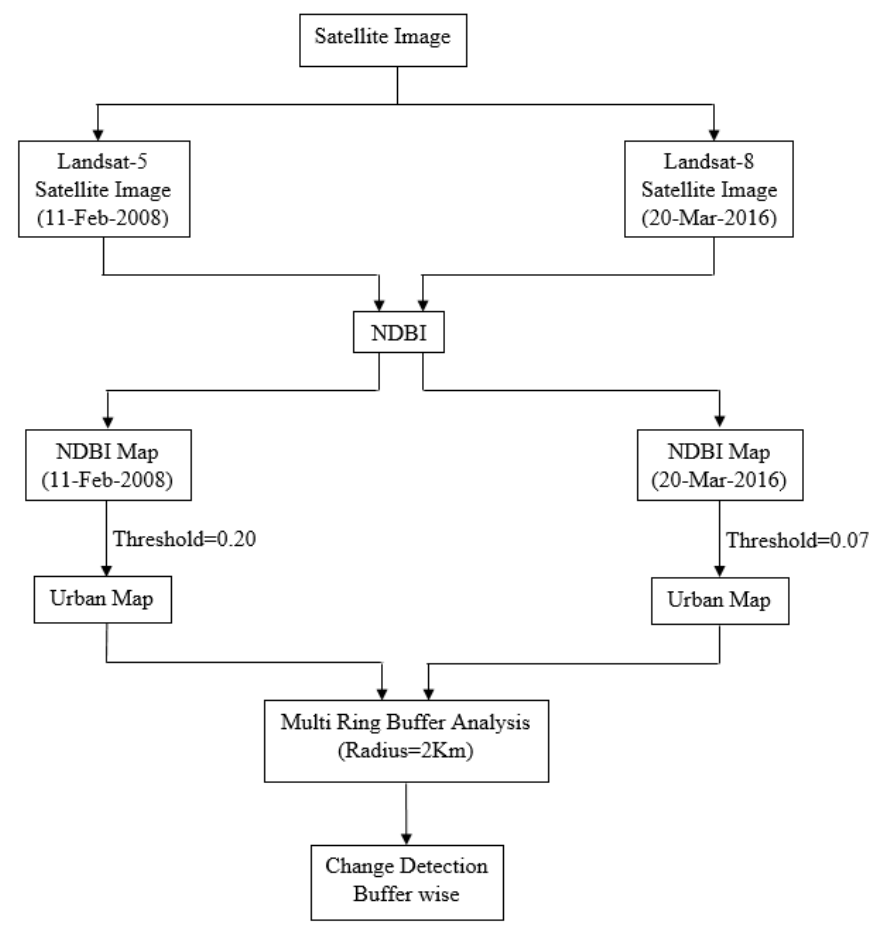

Figure3. Methodology adopted for Multiring Buffer Analysis 


\subsection{Normalized Difference Built-Up Index (NDBI)}

The concept of NDBI in automatically mapping the urban areas from TM imagery was proposed by Zha et al., 2003. NDBI has been recently employed as an indicator to compute the urban built-up areas. This index could differentiate builtup from non-built-up areas. The drastic increment in reflection of built-up area and barren land from NIR to SWIR has been utilized for making the standard differentiation of these two bands.

$$
\mathrm{NDBI}=\frac{\mathrm{SWIR}-\mathrm{NIR}}{\mathrm{SWIR}+\mathrm{NIR}}
$$

The resultant values from this process show values near to zero for vegetated surfaces, negative values for water bodies and highest values for built-up areas and desert surfaces.

\subsection{Multi Ring Buffer Analyses}

Buffers are the rings around the input features that do not overlap and as rings or donuts around the centre point. For analysis of the pattern of urban expansion, 7 buffer rings were generated with the interval of $2 \mathrm{~km}$ from the centre point of the selected study area (Figure 6). The smallest buffer covers the area of its input feature plus the buffer distance, and subsequent buffer rings around the smallest buffer which do not cover the area of the input feature or smaller buffers. Urban area for each ring calculated by Intersect buffer rings with both the urban which are used to visualize and understand the pattern of urban sprawl in Kanpur city.

\section{RESULT AND DISCUSSION}

Rapidly populating urban environment of Kanpur in the last decade has adverse impact over its land cover. Different results obtained after deploying proposed multi ring buffer analysis is summarized in the current section. Implementation of NDBI index over both the satellite images of 2008 and 2016 yield a gradient image of impervious object. Figure 4 (a) and (b) depicts NDBI images for the year 2008 and 2016 respectively. In case of 2008 it is observed that the gradient varies in between -0.60 to 0.53 while in case of 2016 the range of impervious observations is from -0.34 to 0.23 . Using basic thresholding approach urban land use is extracted from the NDBI images. 0.20 is the threshold for 2008 satellite image and 0.07 is the threshold for the 2016 image. Extracted urban region for both the years are presented in the figure 5

(a) and (b). Table 2 shows the urban area for both the year. It is observed that the urban area which was 125.69 square $\mathrm{Km}$ in 2008 is increased up to 178.94 square $\mathrm{Km}$ in 2016. Now in order to have a detailed understand of the impact of urbanization over the land cover of Kanpur city, multi ring buffer analysis with the buffer radius of $2 \mathrm{~km}$ is done and individual area variation from 2008 to 2016 is computed. Multi ring buffer map is presented in the figure 6 . Figure 7(a) and (b) shows the urban area in 0 to $2 \mathrm{~km}$ buffer range for the year 2008 and 2016 respectively. Similarly maps are presented in figure $7(\mathrm{c})$, figure $7(\mathrm{~d})$, figure $7(\mathrm{e})$, figure $7(\mathrm{f})$, figure $7(\mathrm{~g})$, figure $7(\mathrm{~h})$, figure $7(\mathrm{i})$, figure $7(\mathrm{j})$, figure $7(\mathrm{k})$, figure $7(\mathrm{l})$, figure $7(\mathrm{~m})$, figure $7(\mathrm{n})$ present urban variations in from $2 \mathrm{~km}$ to $14 \mathrm{~km}$ with the buffer radius of $2 \mathrm{~km}$ each. Urban area is computed in individual map and summarized in the table 3 . Graph 1 is drawn on the basis of urban area statistics from table 3. Graph 1 helps to understand the detailed impact of urbanization in terms of growing impervious surfaces from city center in Kanpur. It is evident that city center is a rich urban zone where land in 2008 is almost converted in to urban. Marginal increment in urban area is noticed in 0 to $2 \mathrm{~km}$ and 2 to $4 \mathrm{~km}$ buffer zone. The central part of Kanpur city is moderately urbanized and in comparison to 2008 urban built up area is found increasing in 2016.

Residential, commercial and industrial zone already existed in the 4 to $8 \mathrm{~km}$ radius of the city, similar to city center this part also have marginal increment in urban areas. Major changes are noticed in the outskirt of the city where construction of highway, establishment of new industries and commercial zone changes the profile of land cover. Increment in construction activated and resulted significant improvement in impervious surfaces.

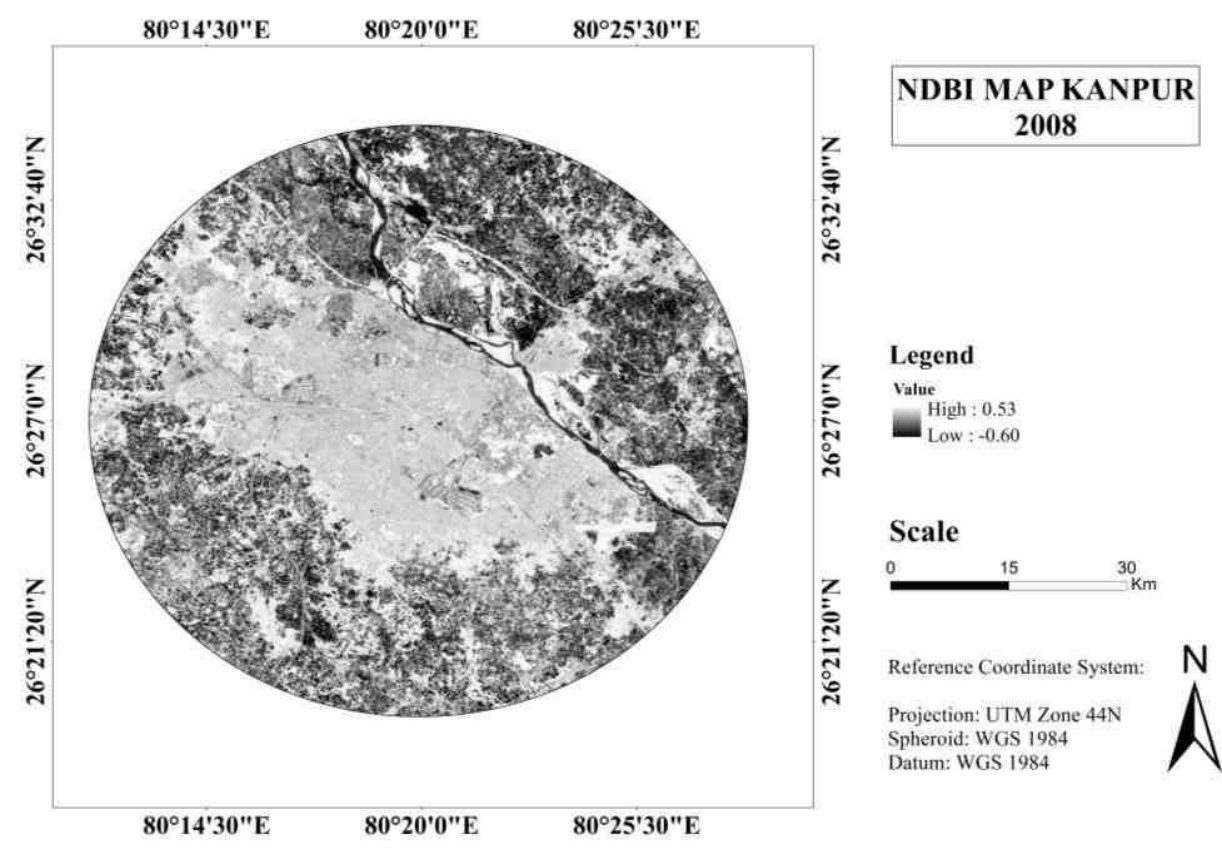

Figure4. (a) NDBI Map of Study Area 

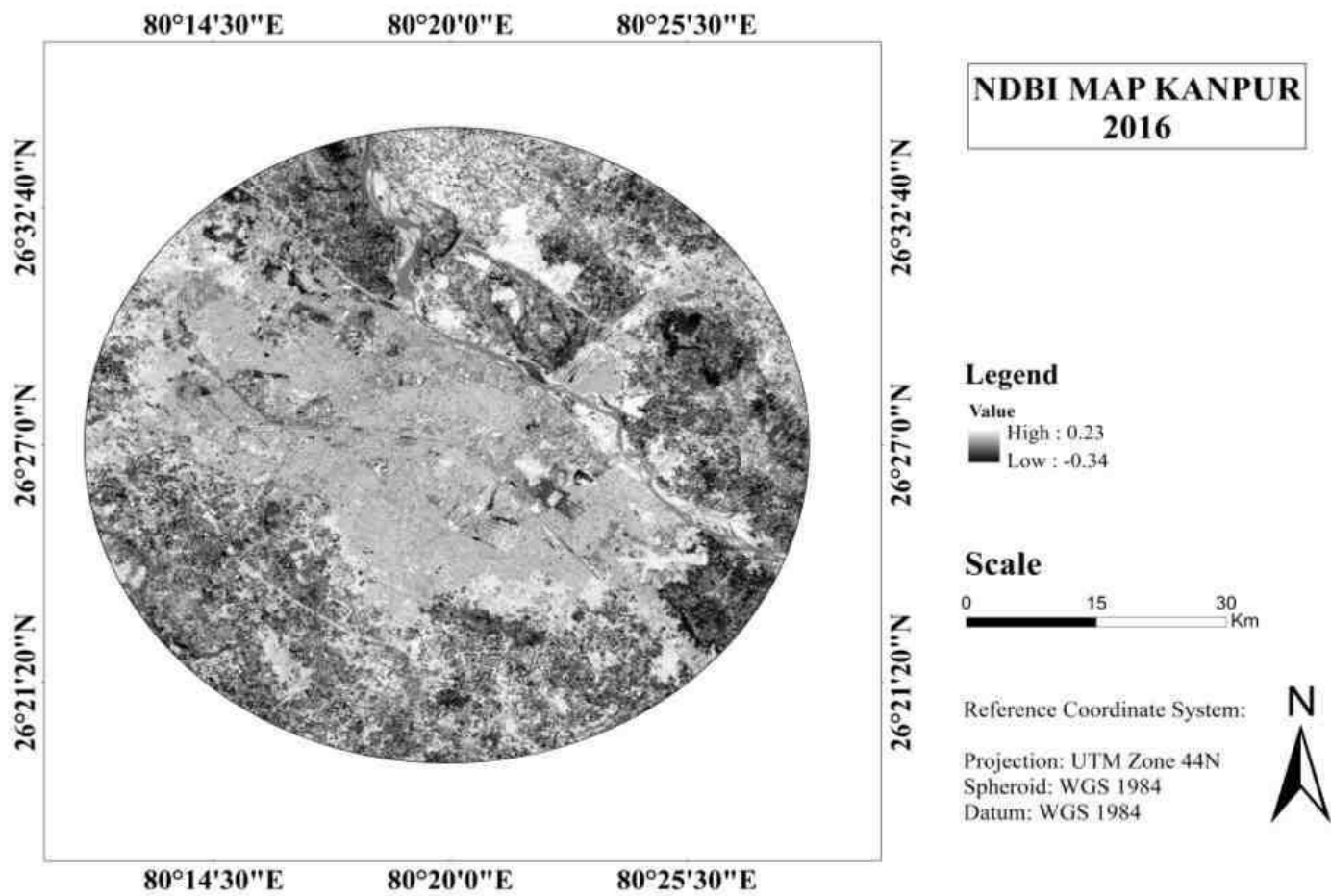

Figure4. (b) NDBI Map of Study Area

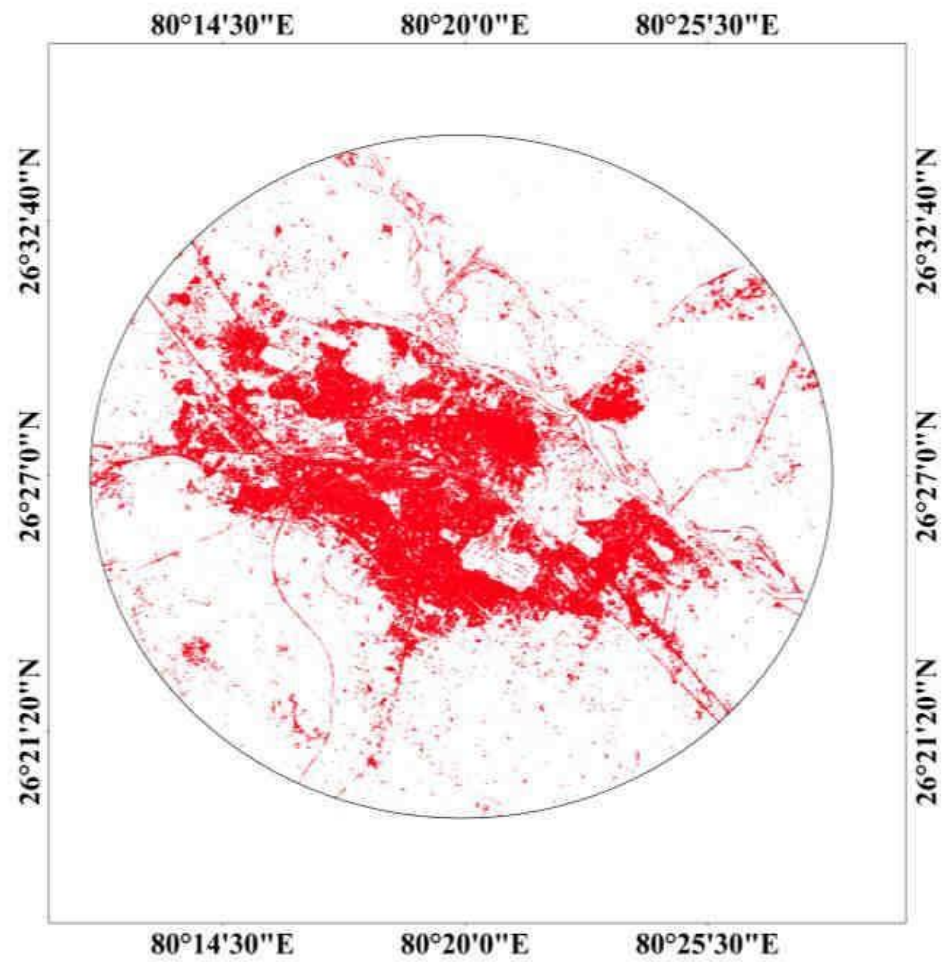

URBAN MAP KANPUR 2008

Figure5. (a) Urban Map of Study Area 


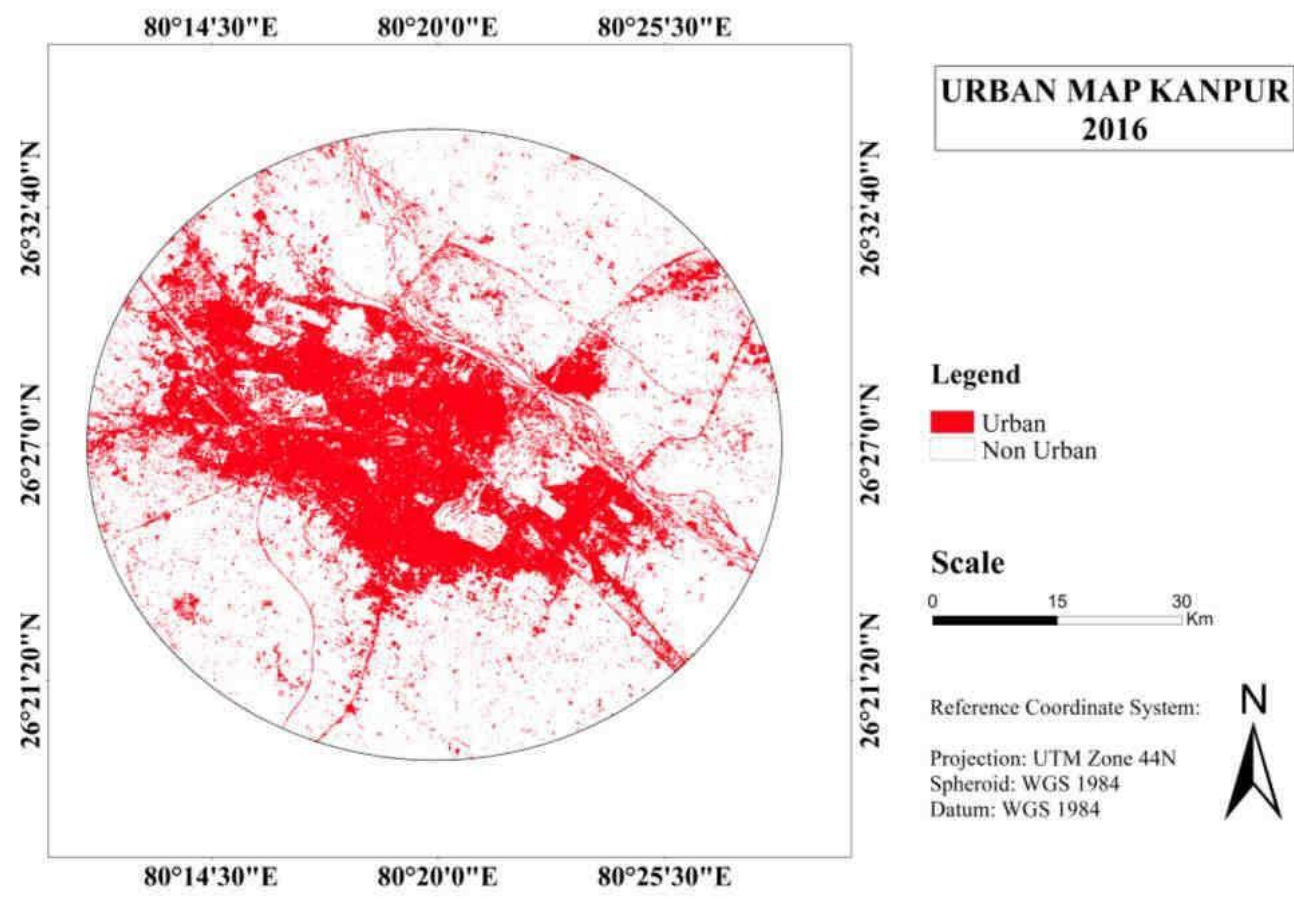

Figure5. (b) Urban Map of Study Area

Table2. Urban area of Study area

\begin{tabular}{|c|c|c|}
\hline Year & $\mathbf{2 0 0 8}$ & $\mathbf{2 0 1 6}$ \\
\hline Urban Area $\left(\mathbf{k m}^{\mathbf{2}}\right)$ & 125.69 & 178.94 \\
\hline
\end{tabular}
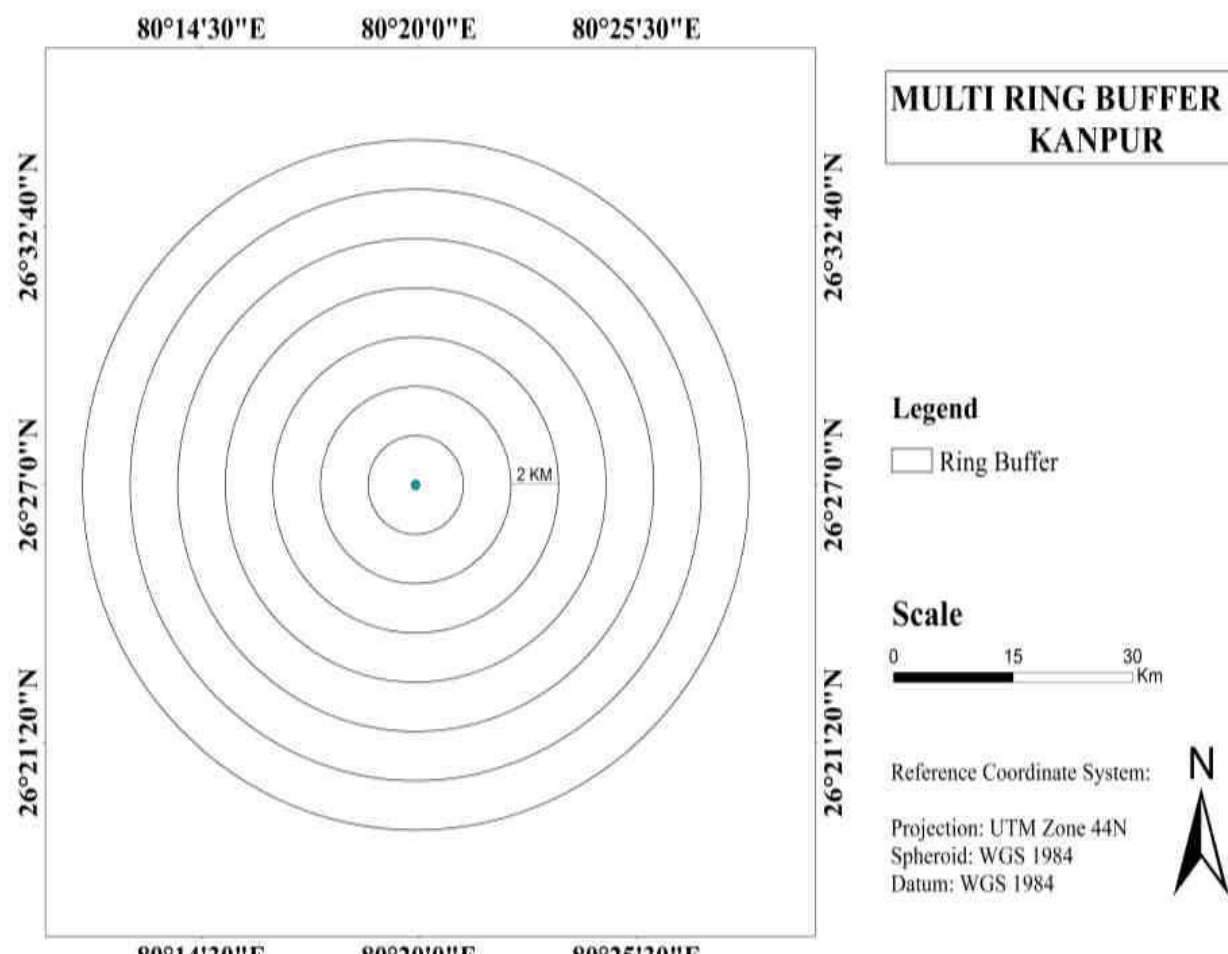

$80^{\circ} 14^{\prime} 30^{\prime \prime} \mathrm{E}$

$80^{\circ} 20^{\prime} 0^{\prime \prime} \mathrm{E}$

$80^{\circ} 250^{\prime \prime} \mathrm{E}$

Figure6. Multi Ring Buffer of Study Area 


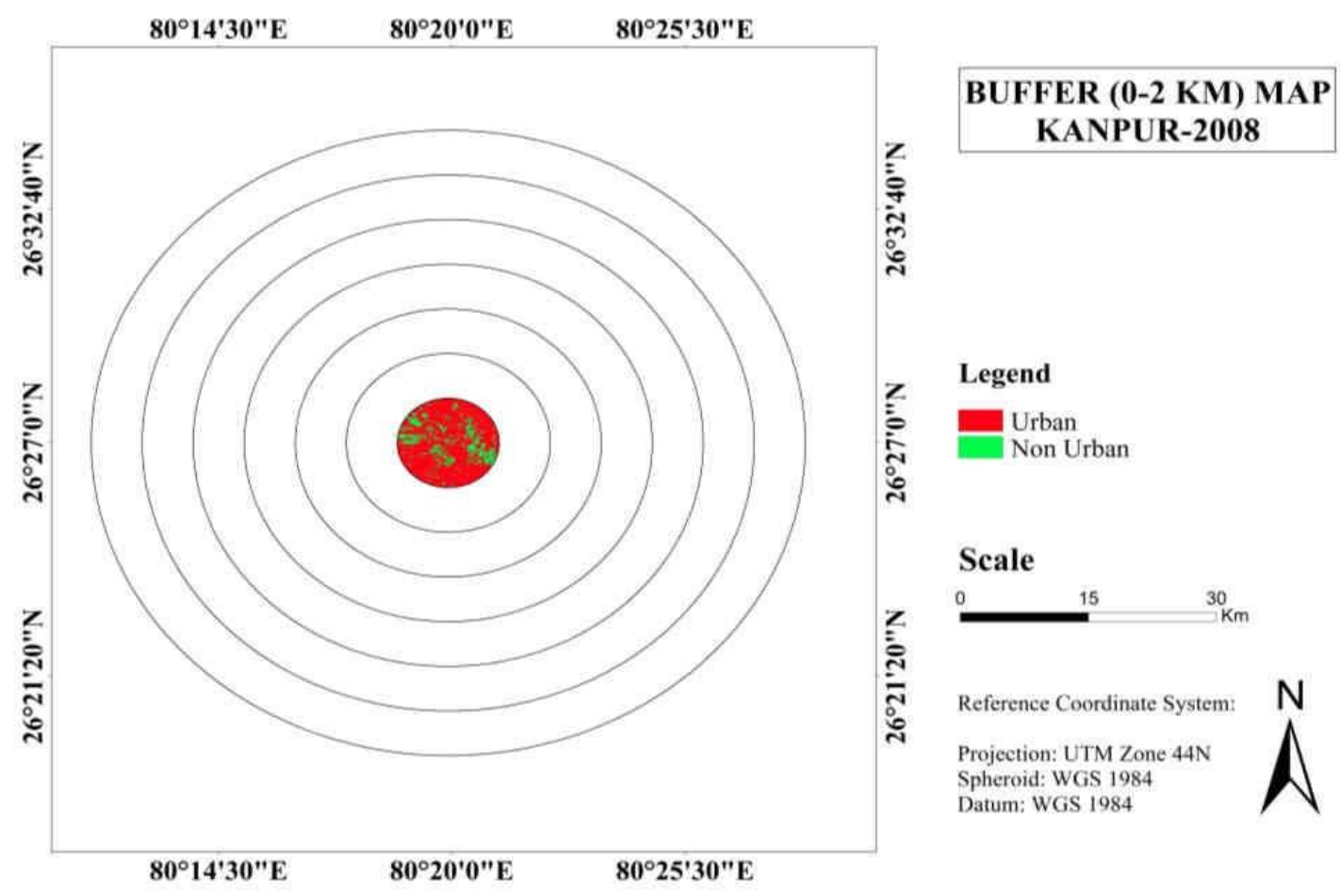

(a)

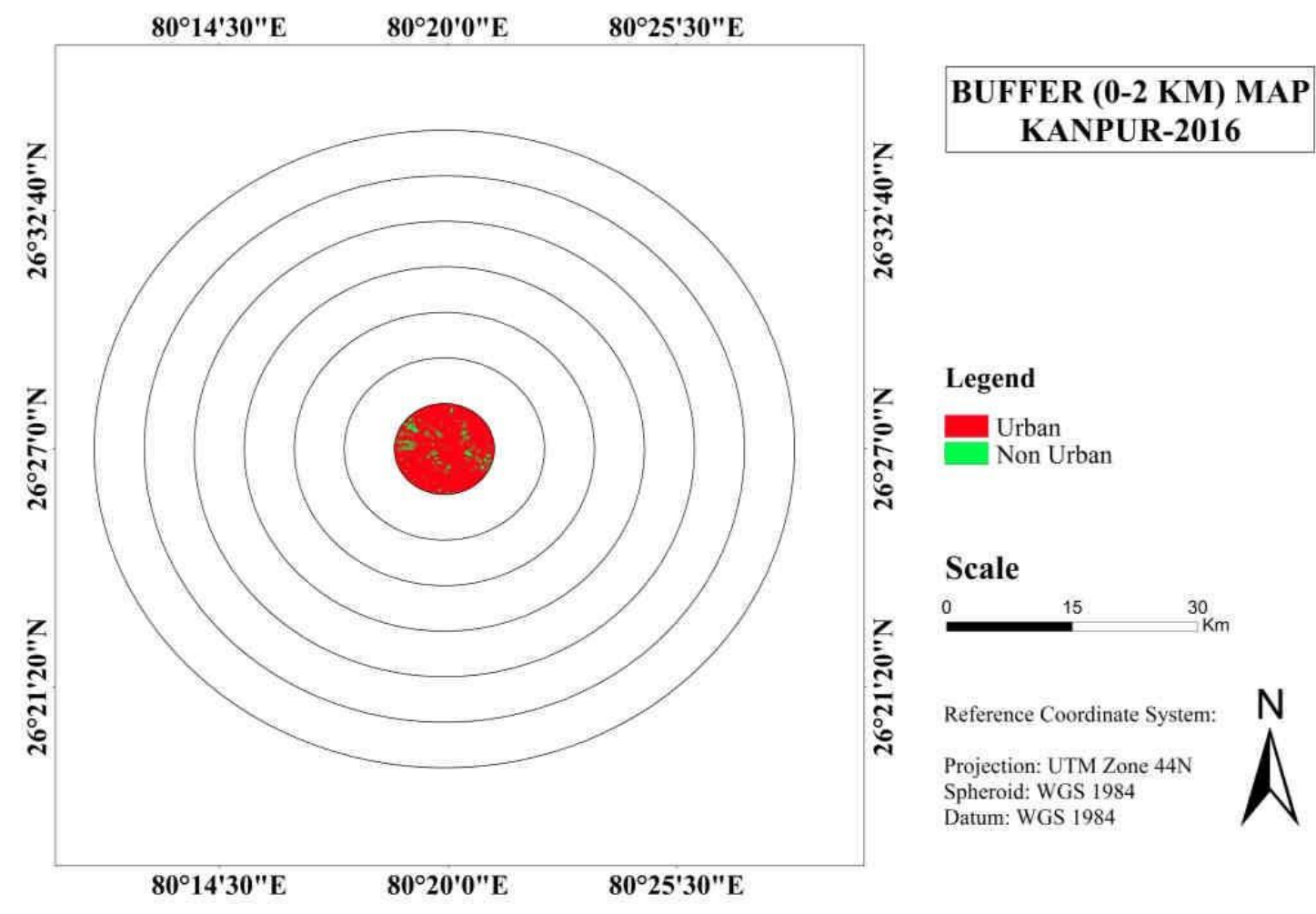

(b) 

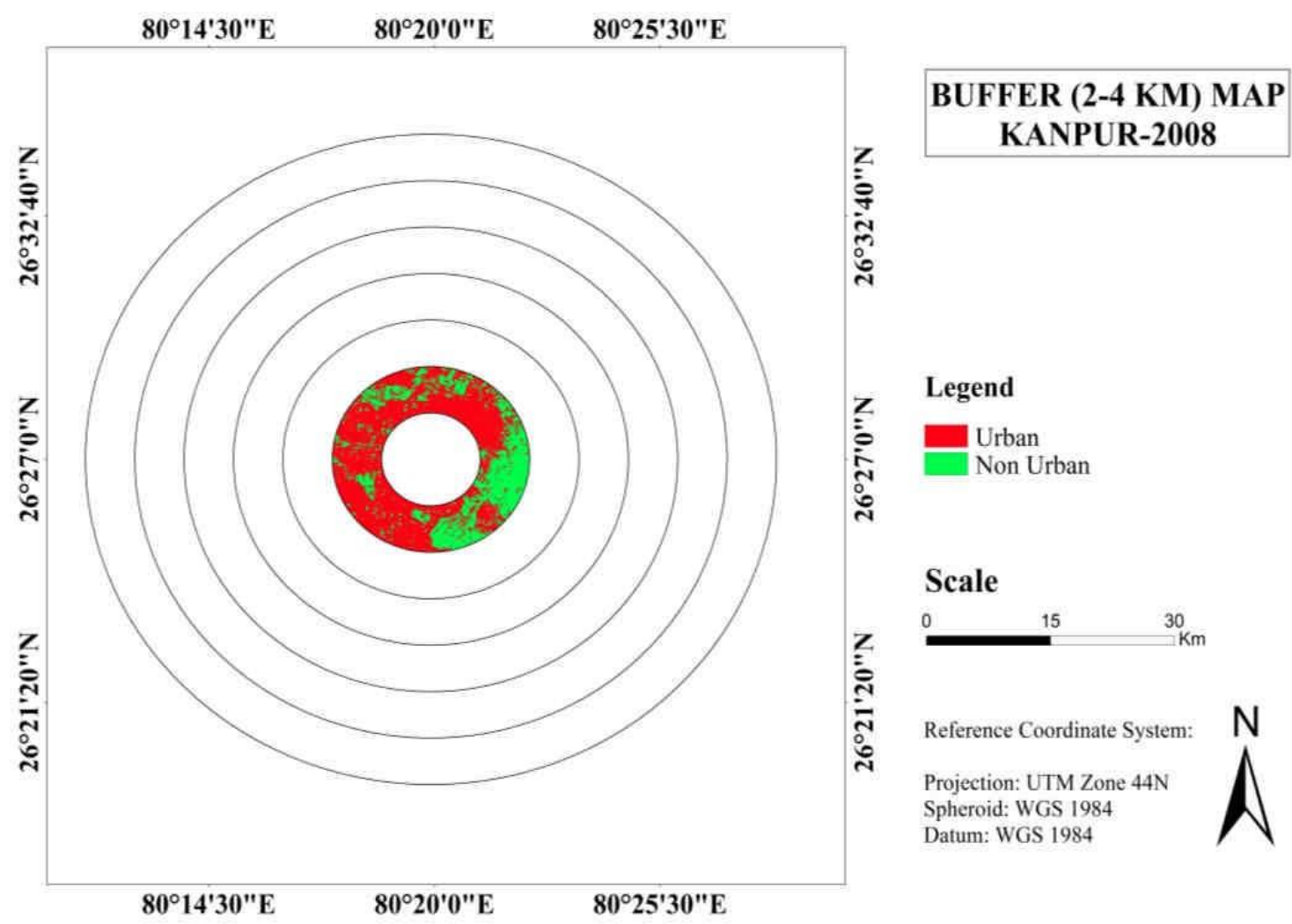

(c)

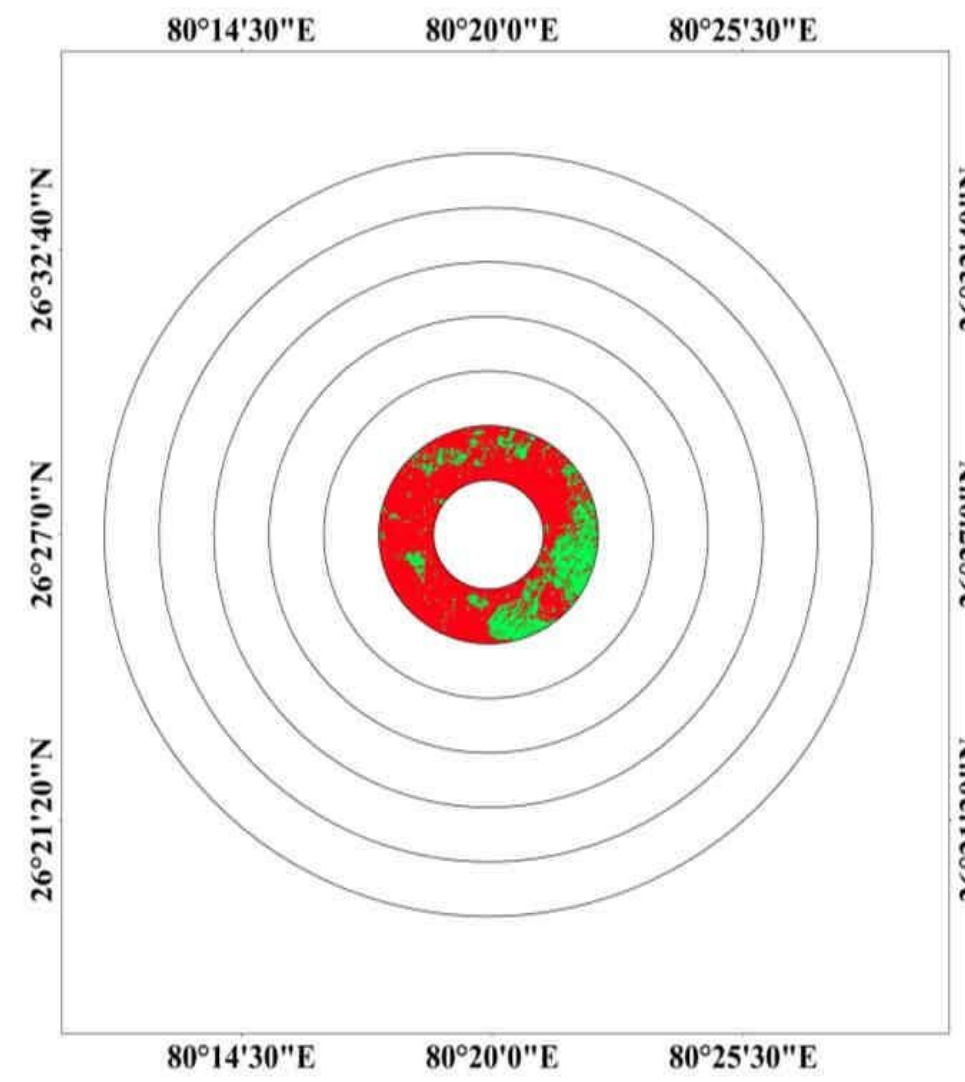

BUFFER (2-4 KM) MAP KANPUR-2016

\section{Scale}

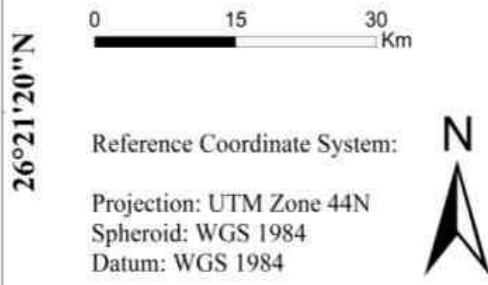

ปे

Legend

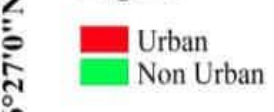

(d) 

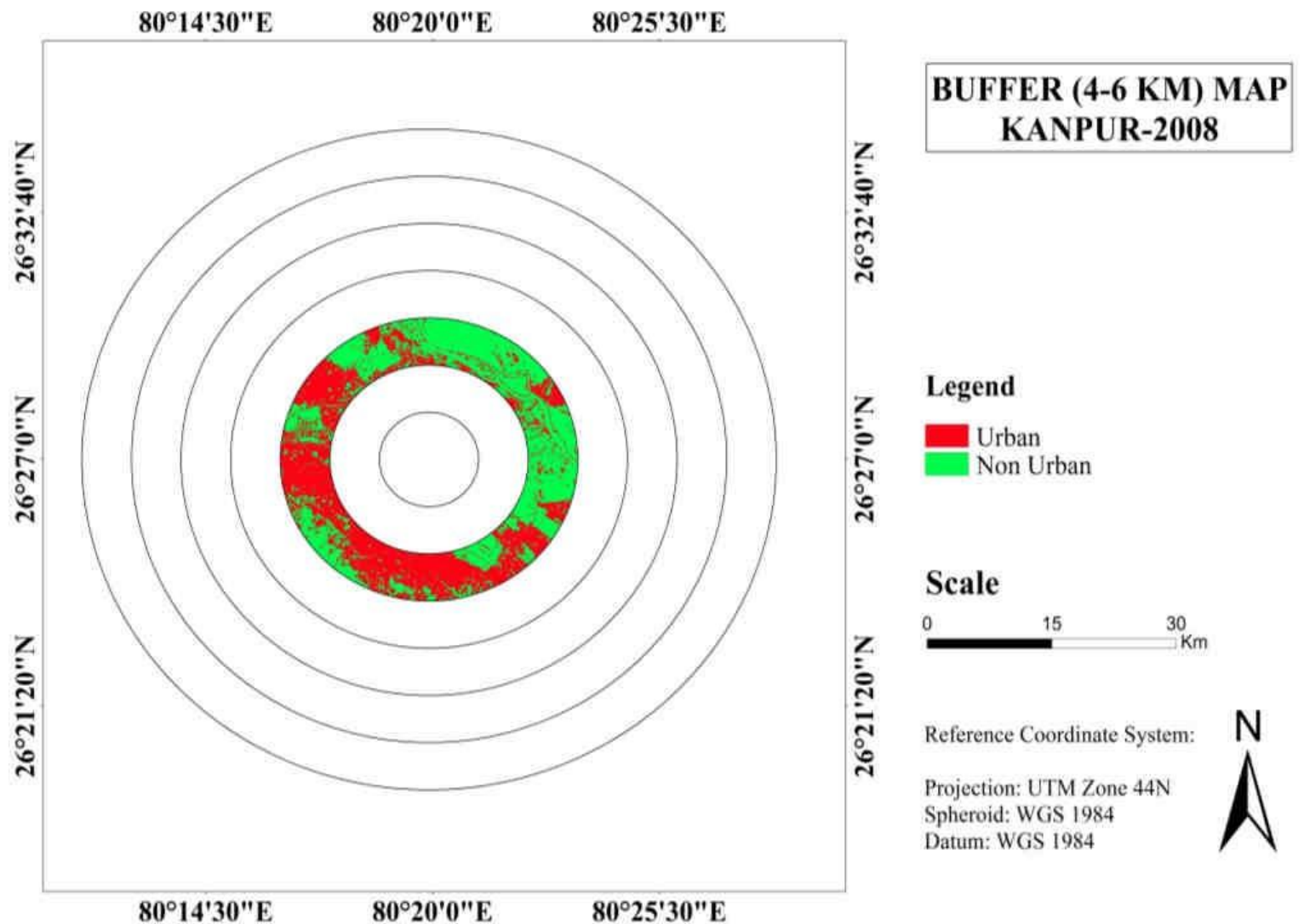

$80^{\circ} 14^{\prime} 30^{\prime \prime} \mathrm{E} \quad 80^{\circ} 20^{\prime} 0 " \mathrm{E} \quad 80^{\circ} 25^{\prime} 30^{\prime \prime} \mathrm{E}$

(e)

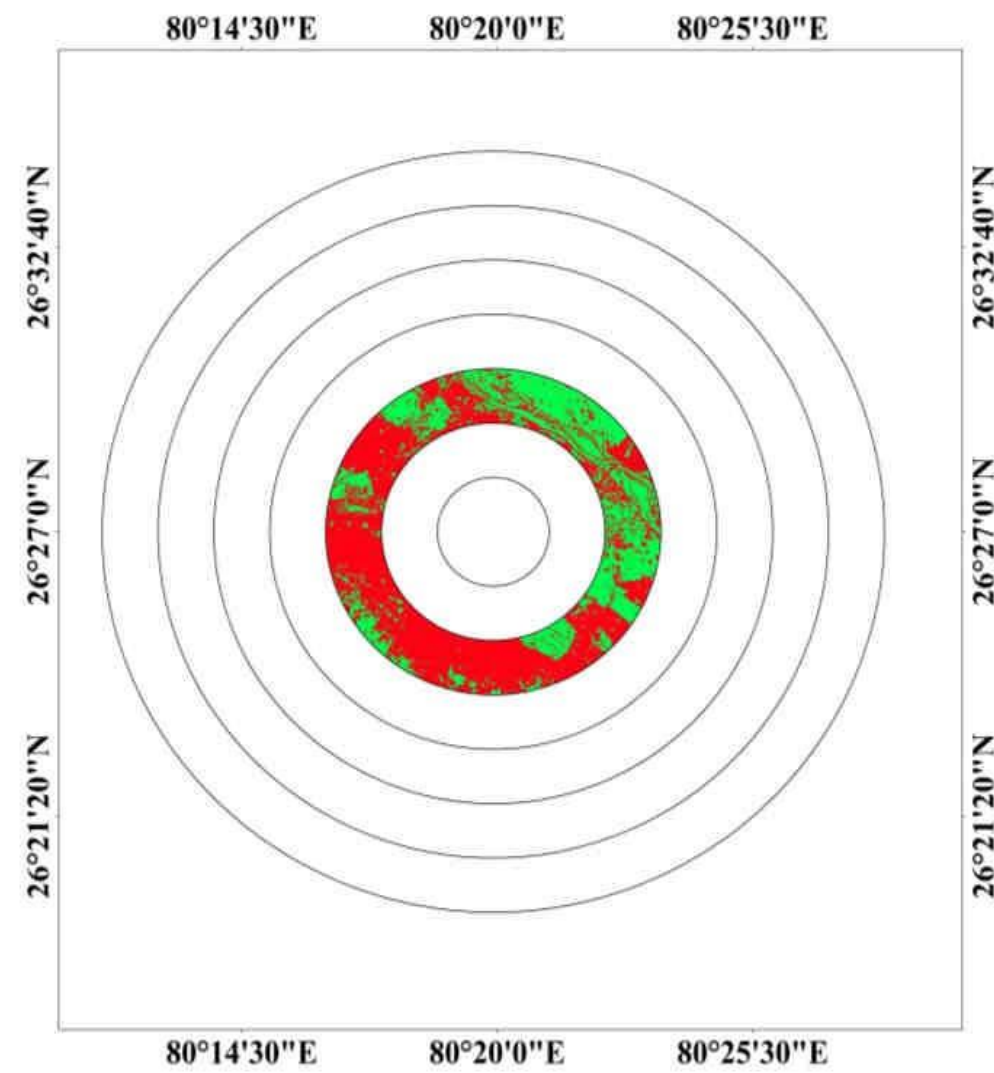

BUFFER (4-6 KM) MAP KANPUR-2016

\section{Scale}

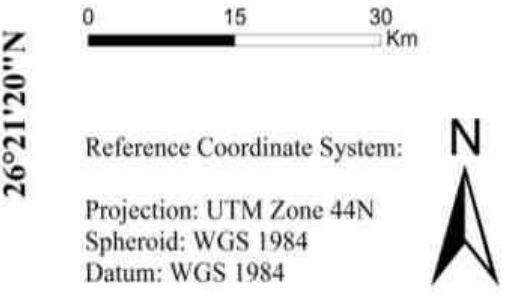

Datum: WGS 1984

(f) 

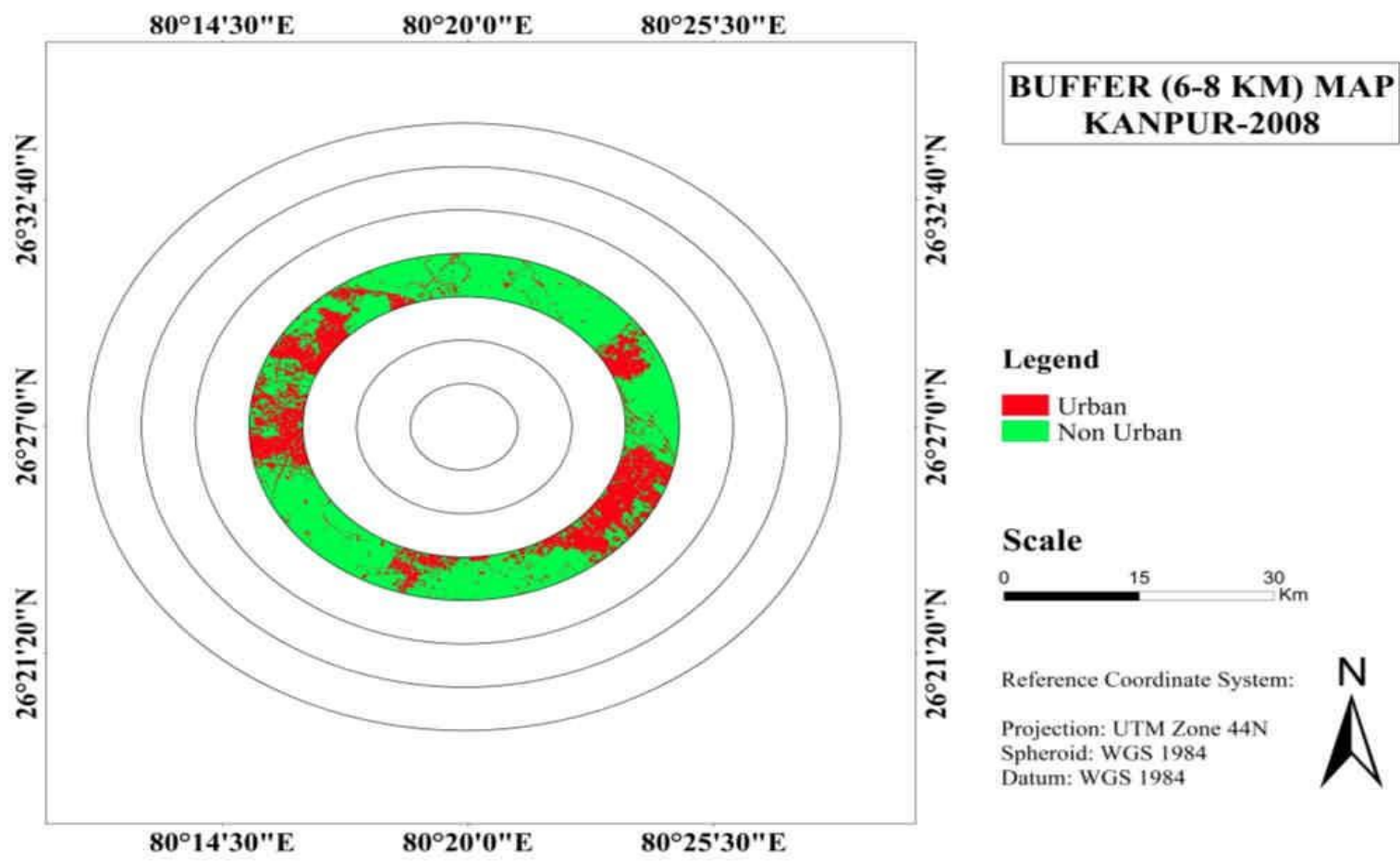

(g)

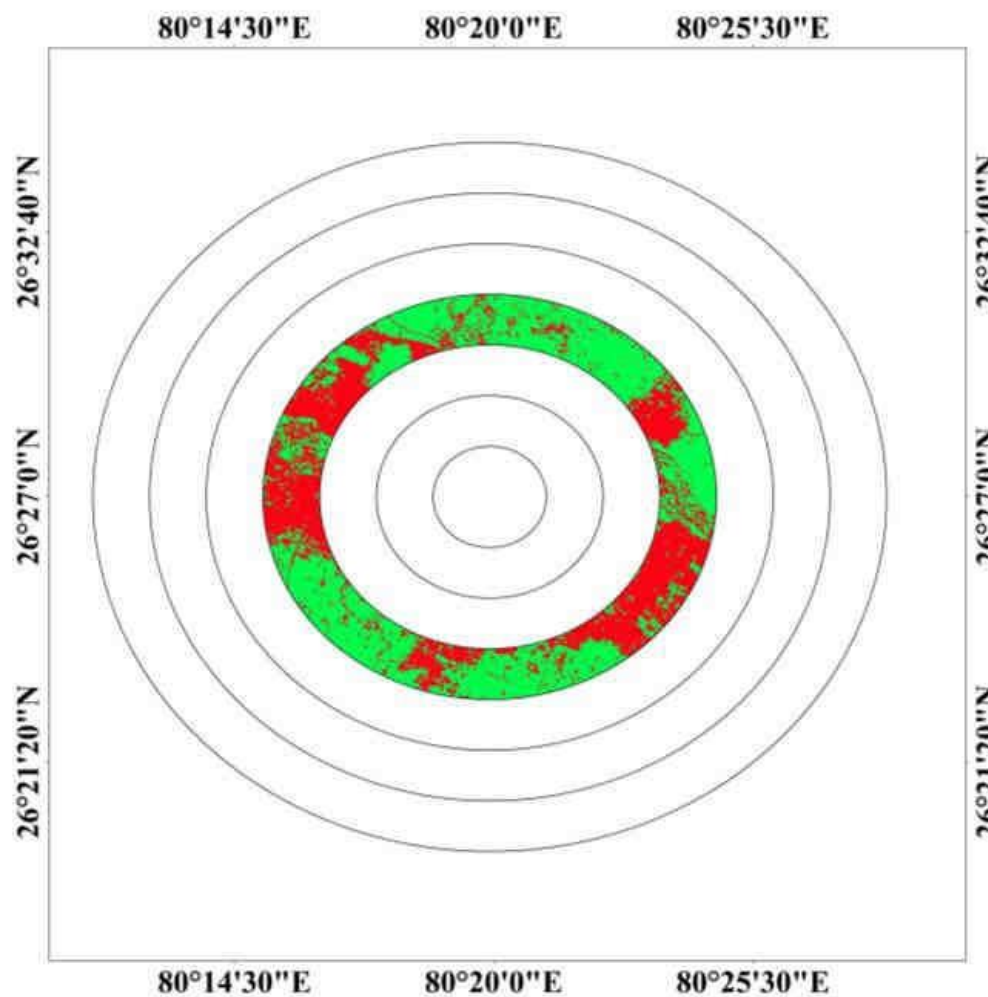

BUFFER (6-8 KM) MAP KANPUR-2016

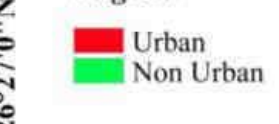

(h) 

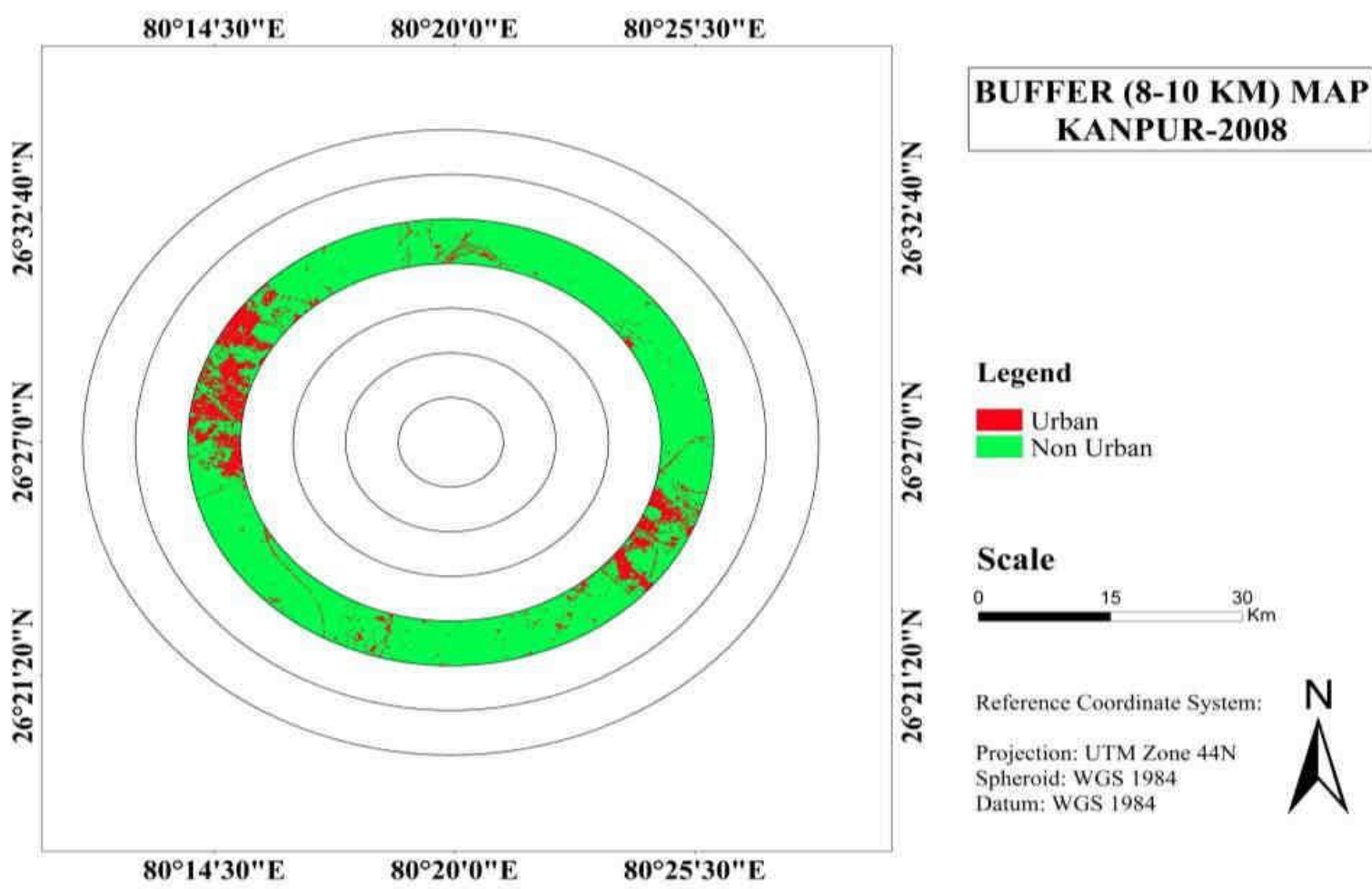

(i)
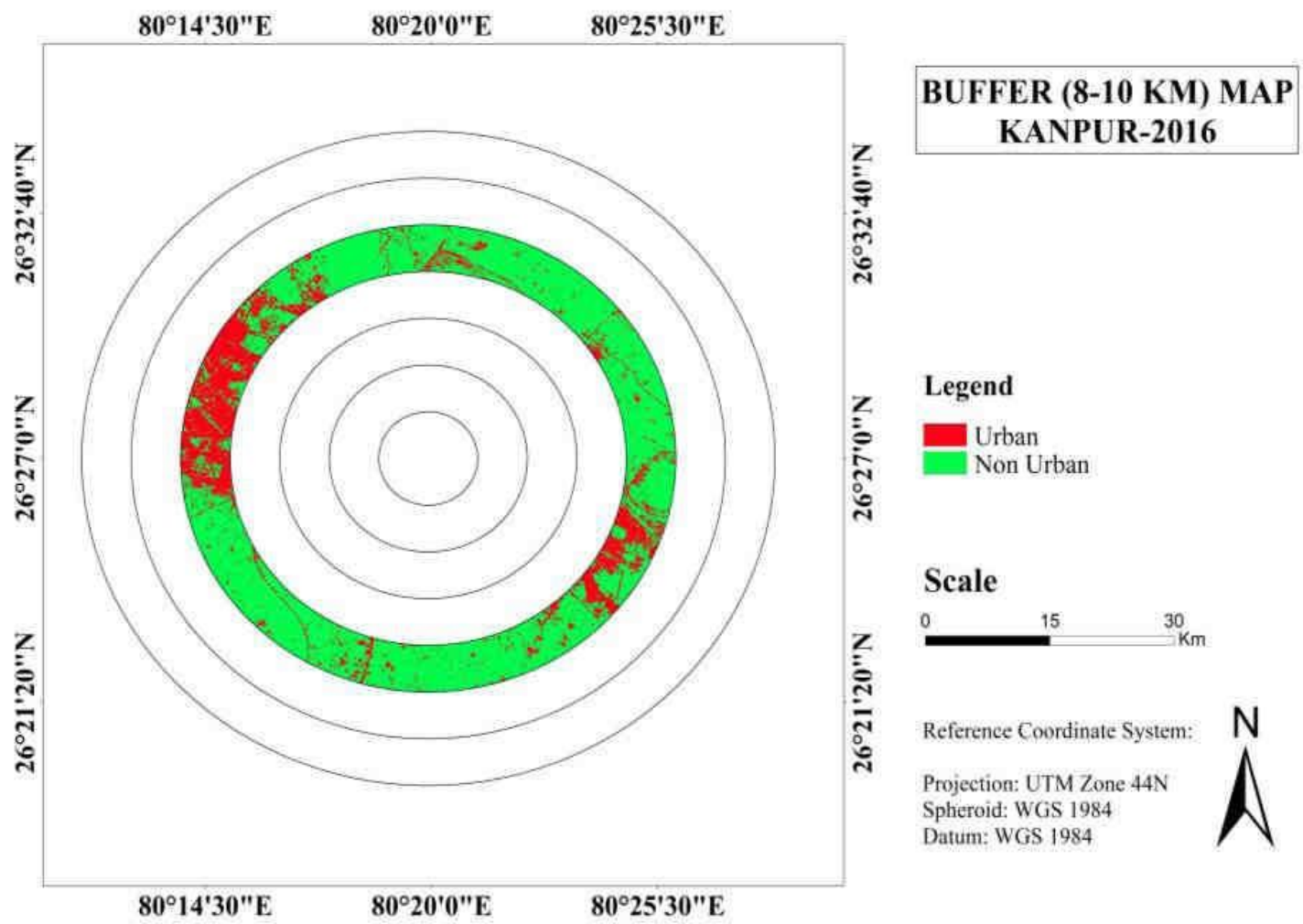

Reference Coordinate System

Projection: UTM Zone 44N

Spheroid: WGS 1984

Datum: WGS 1984
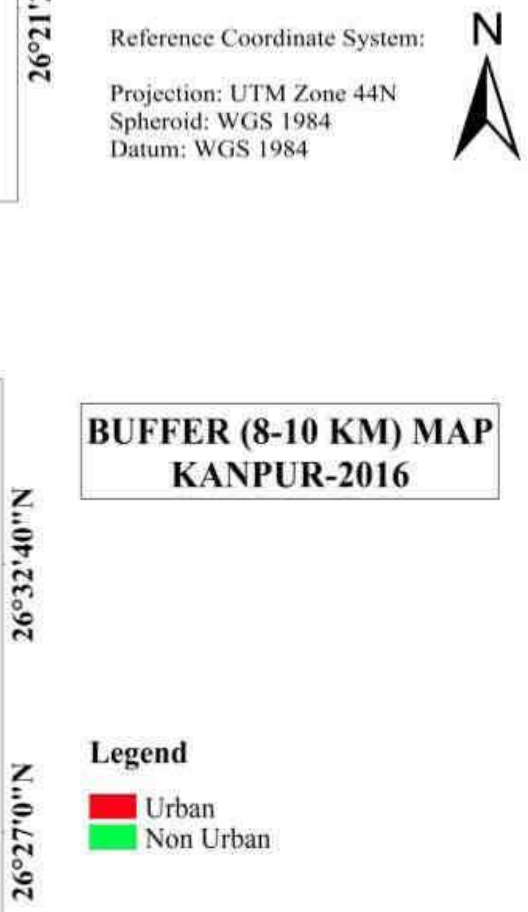

(j)

Scale

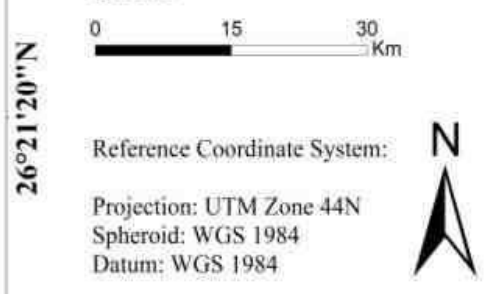



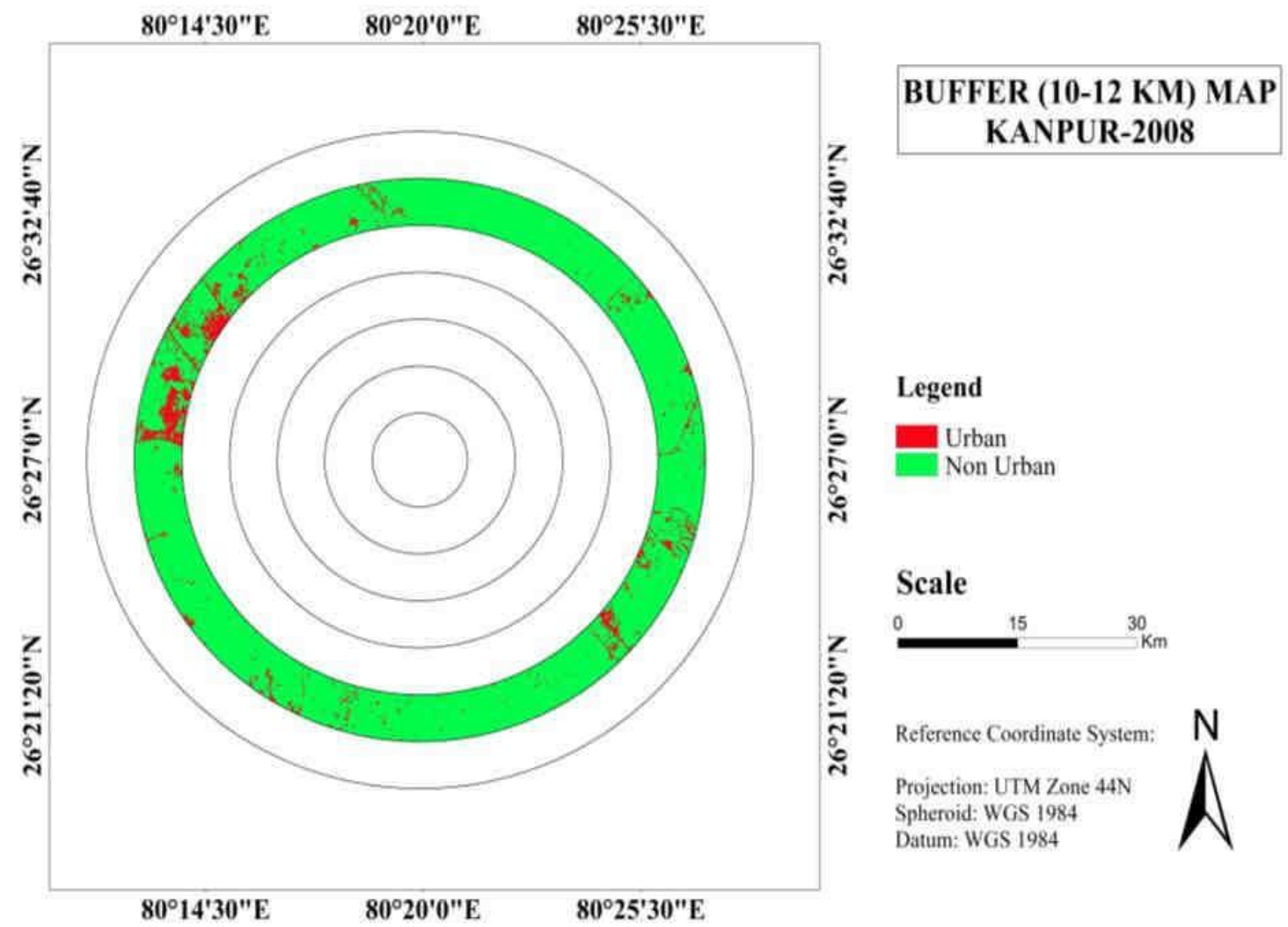

(k)

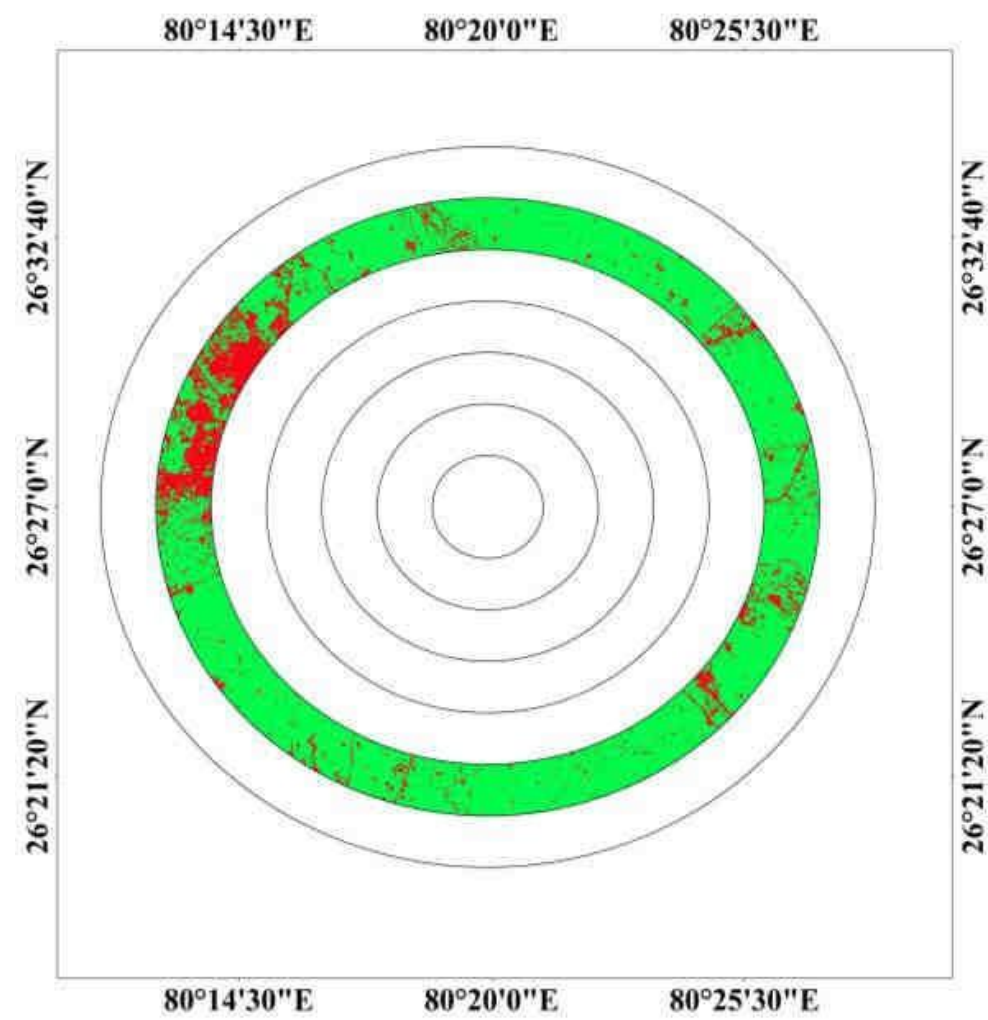

BUFFER (10-12 KM) MAP KANPUR-2016

Legend

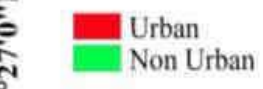

\section{Scale}

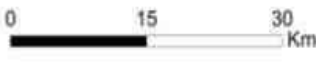

Reference Coordinate System:

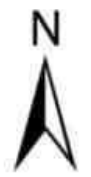

Spheroid: WGS 1984

Datum: WGS 1984

Legend

Urban

\section{Scale}

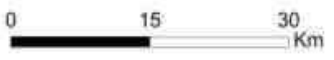

Reference Coordinate System:

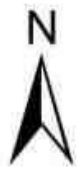

Spheroid: WGS 1984

Datum: WGS 1984 

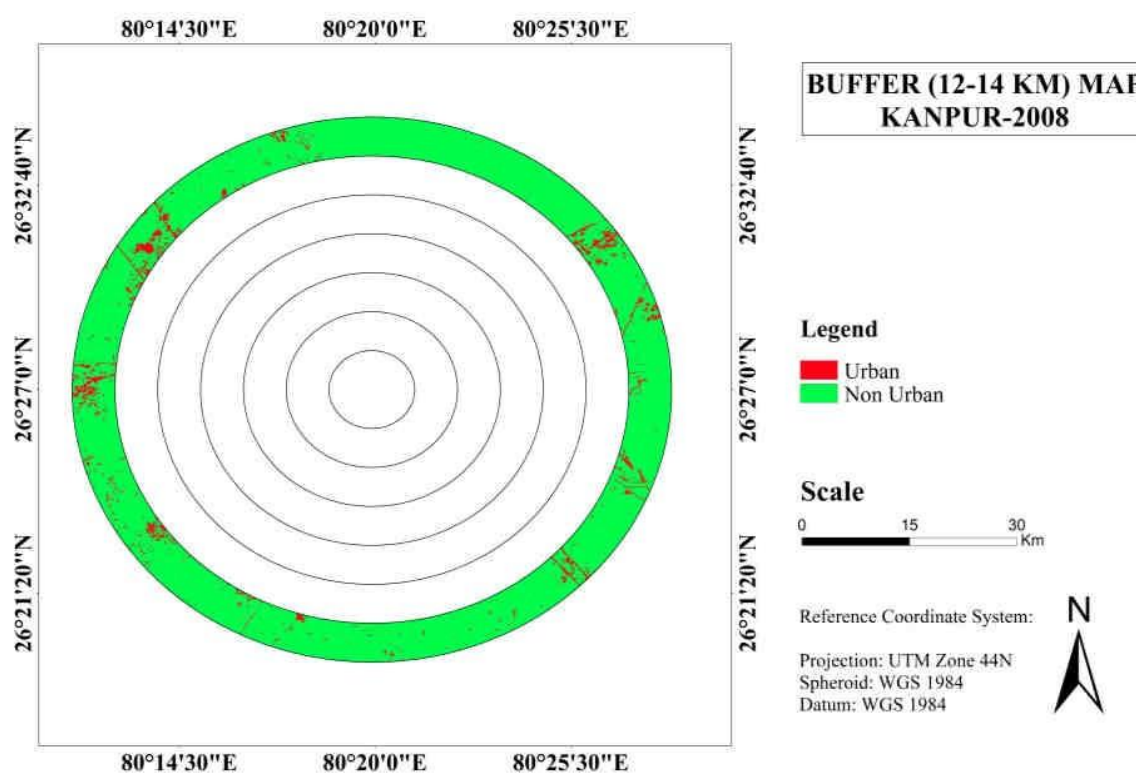

(m)
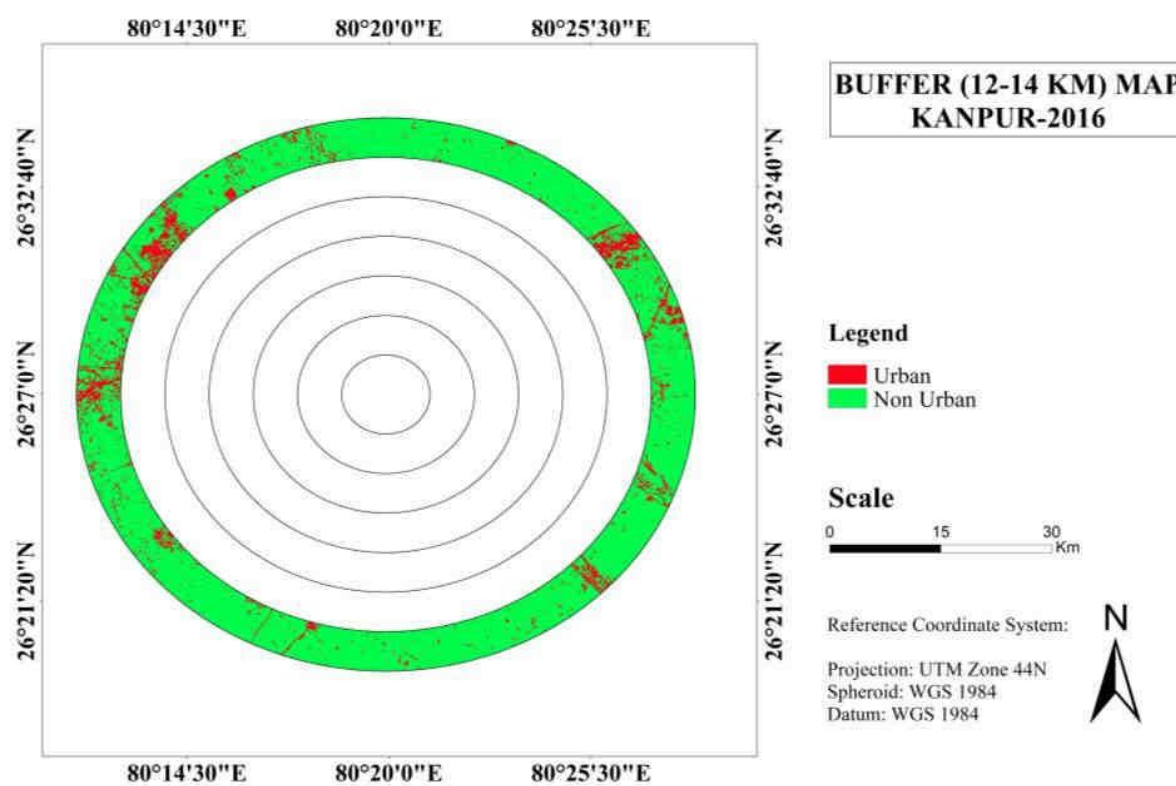

(n)

Figure7. Multi Buffer Map of Study Area

Table3. Multi Ring Buffer Urban Area

\begin{tabular}{|c|c|c|c|c|c|c|c|c|c|c|c|c|c|c|}
\hline \multirow[b]{2}{*}{ Year } & \multicolumn{2}{|c|}{ 0-2 Km } & \multicolumn{2}{|c|}{ 2-4 Km } & \multicolumn{2}{|c|}{ 4-6 Km } & \multicolumn{2}{|c|}{ 6-8 Km } & \multicolumn{2}{|c|}{ 8-10 Km } & \multicolumn{2}{|c|}{ 10-12 KM } & \multicolumn{2}{|c|}{ 12-14 KM } \\
\hline & $\begin{array}{l}\text { Total } \\
\text { Area } \\
\left(\mathbf{K m}^{2}\right) \\
\end{array}$ & $\begin{array}{c}\text { Urban } \\
\text { Area } \\
\left(\mathbf{K m}^{2}\right) \\
\end{array}$ & $\begin{array}{l}\text { Total } \\
\text { Area } \\
\left(\mathbf{K m}^{2}\right) \\
\end{array}$ & $\begin{array}{c}\text { Urban } \\
\text { Area } \\
\left(\mathbf{K m}^{2}\right) \\
\end{array}$ & $\begin{array}{l}\text { Total } \\
\text { Area } \\
\left(\mathbf{K m}^{2}\right) \\
\end{array}$ & $\begin{array}{c}\text { Urban } \\
\text { Area } \\
\left(\mathbf{K m}^{2}\right) \\
\end{array}$ & $\begin{array}{l}\text { Total } \\
\text { Area } \\
\left(\mathbf{K m}^{2}\right) \\
\end{array}$ & $\begin{array}{c}\text { Urban } \\
\text { Area } \\
\left(\mathbf{K m}^{2}\right)\end{array}$ & $\begin{array}{l}\text { Total } \\
\text { Area } \\
\left(\mathbf{K m}^{2}\right)\end{array}$ & $\begin{array}{c}\text { Urban } \\
\text { Area } \\
\left(\mathbf{K m}^{2}\right) \\
\end{array}$ & $\begin{array}{l}\text { Total } \\
\text { Area } \\
\left(\mathbf{K m}^{2}\right) \\
\end{array}$ & $\begin{array}{c}\text { Urban } \\
\text { Area } \\
\left(\mathbf{K m}^{2}\right) \\
\end{array}$ & $\begin{array}{l}\text { Total } \\
\text { Area } \\
\left(\mathbf{K m}^{2}\right) \\
\end{array}$ & $\begin{array}{c}\text { Urban } \\
\text { Area } \\
\left(\mathbf{K m}^{2}\right)\end{array}$ \\
\hline 2008 & 12.56 & 10.18 & 37.65 & 25.00 & 62.81 & 30.15 & 87.86 & 26.74 & 113.04 & 15.71 & 137.95 & 9.65 & 163.23 & 8.19 \\
\hline 2016 & 12.56 & 11.48 & 37.65 & 28.33 & 62.81 & 38.03 & 87.86 & 36.42 & 113.04 & 26.4 & 137.95 & 20.29 & 163.23 & 17.81 \\
\hline
\end{tabular}




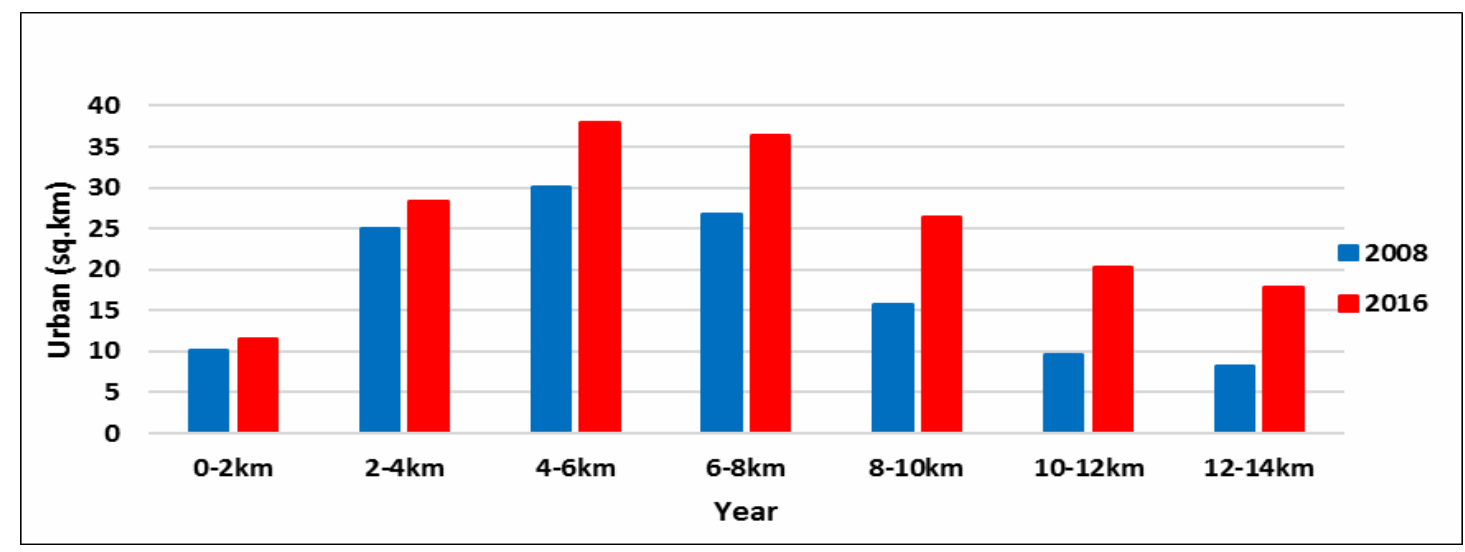

Graph1. Urban Area graph of Study Area

\section{CONCLUSIONS}

The current study demonstrated that remote sensing is an efficient technology to compute the spatial extent of urbanization. The openly available satellite images of Landsat mission provide unique opportunity to quantify implications of human activities in urban ecosystem. Kanpur is rapidly growing urban center in one of the biggest states of India. Multi Ring Buffer analysis from city center and with the small radius of $2 \mathrm{Km}$ helps to draw some distinguish conclusions regarding the nature of urban sprawl and the dynamics of city growth

On the one hand where previously occupied city center provides less space of development on the other hand outskirt shows rich development opportunities for both the industrial and residential options. Although the spatial and temporal extent of urban transformations can be defined with the current study, conclusions regarding the direction and trend require some sophisticated statistics techniques.

\section{REFERENCES}

[1] Angel, S., Parent, J. and Civco, D., 2007, May. Urban sprawl metrics: an analysis of global urban expansion using GIS. In Proceedings of ASPRS 2007 Annual Conference, Tampa, Florida May (Vol. 7, No. 11).

[2] Barnes, K.B., Morgan III, J.M., Roberge, M.C. and Lowe, S., 2001. Sprawl development: Its patterns, consequences, and measurement. Towson University, Towson, pp.1-24.

[3] Epstein, J., Payne, K. and Kramer, E., 2002. Techniques for mapping suburban sprawl. Photogrammetric engineering and remote sensing, 68(9), pp.913-918.

[4] Herold, M., Goldstein, N.C. and Clarke, K.C., 2003. The spatiotemporal form of urban growth: measurement, analysis and modeling. Remote sensing of Environment, 86(3), pp.286-302.

[5] Kumar, J.A.V., Pathan, S.K. and Bhanderi, R.J., 2007. Spatio-temporal analysis for monitoring urban growth-a case study of Indore city. Journal of the Indian Society of Remote Sensing, 35(1), pp.11-20.
[6] Pathan, S.K., Jothimahi, P., Kumar, D.S. and Pendharkar, S.P., 1989. Urban land use mapping and zoning of Bombay Metropolitan Region using Remote Sensing data. Journal of the Indian Society of Remote Sensing, 17(3), pp.11-22.

[7] Pathan, S.K., Shukla, V.K., Patel, R.G., Patel, B.R. and Mehta, K.S., 1991. Urban land use mapping: a case study of Ahmedabad city and its environs. Journal of the Indian Society of Remote Sensing, 19(2), pp.95-112.

[8] Stefanov, W.L., Ramsey, M.S. and Christensen, P.R., 2001. Monitoring urban land cover change: An expert system approach to land cover classification of semiarid to arid urban centers. Remote sensing of Environment, 77(2), pp.173-185.

[9] Tiwari, A. and Dixit, A., 2015. Unmanned aerial vehicle and geospatial technology pushing the limits of development. American Journal of Engineering Research, 4, pp.16-21.

[10] Tiwari, A. and Jain, K., 2014. GIS Steering smart future for smart Indian cities. International Journal of Scientific and Research Publications, 4(8), pp.442-446.

[11] Tiwari, A., Suresh, M., Jain, K., Shoab, M., Dixit, and Pandey, A., 2018. Urban Landscape Dynamics for Quantifying the Changing Pattern of Urbanisation in Delhi. Journal of Rural Development, 37(2), pp.399-412.

[12] Wilson, E.H., Hurd, J.D., Civco, D.L., Prisloe, M.P. and Arnold, C., 2003. Development of a geospatial model to quantify, describe and map urban growth. Remote sensing of environment, 86(3), pp.275-285.

[13] Zha, Y., Gao, J. and Ni, S., 2003. Use of normalized difference built-up index in automatically mapping urban areas from TM imagery. International journal of remote sensing, 24(3), pp.583-594. 